\title{
Work in Progress - The Development of Agency in a High School Maker Class: Evidence from Interviews
}

\section{Prof. Lee Michael Martin, University of California, Davis}

Lee Martin studies people's efforts to enhance their own learning environments, with a particular focus on mathematical, engineering, and design thinking. In everyday settings, he looks at the varied ways in which people assemble social, material, and intellectual resources for problem solving and learning. In school settings, he looks to find ways in which schools might better prepare students to be more resourceful and flexible in fostering their own learning. 


\section{WORK IN PROGRESS - The Development of Agency in a High-School Maker Class: Evidence from Interviews}

The Work-in-Progress Paper examines youth self-efficacy, as an aspect of youth agency, in the context of participation in maker education activities.

There is growing interest in making and the "maker movement" as context for the development of both cognitive and affective factors related to engineering. Maker experiences can lead people gain interest in design and technology [1] and provide experiences that can foster the development of adaptive expertise [2]. Another hypothesized benefit of engagement in hands-on, do-it-yourself, or "maker" activities is an increased sense of agency - self confidence in the ability to complete projects and make change in the world [3,4]. While there is good evidence that agency and self-efficacy are critical for student success [5], relatively little is known about what agency looks like in maker contexts, nor how it develops over time. In this paper, we investigate if and how student agency develops within a high school maker program.

\section{Theoretical Framework}

Self-efficacy is an individual's belief in their ability to complete tasks in a given domain [6]. A robust body of literature has shown that individuals' self-efficacy is an important predictor of their likelihood of engaging, persisting, and successfully participating in many academic domains [7], and is also a predictor of future career choice [8]. Within engineering, self-efficacy is a predictor of motivation $[9,10]$. Both in school and out-of-school experiences can build selfefficacy in a domain. Students who engaged in pre-college engineering hobbies showed significant gains in self-efficacy [11].

In this work-in-progress paper, we investigate students' self-efficacy through their statements in an informal interview context. Self-efficacy is generally assessed through self-report measures. Surveys are most common, but interviews are also an established and useful method for selfefficacy and related constructs [12].

Our research question is an exploratory one: what are the forms of self-efficacy in making that students develop and express during their participation in a school-based makerspace, and how do these develop over time?

\section{Study context, participants, and data corpus}

The study took place in a diverse public charter high school in California. In partnership with a classroom teacher, we collaboratively ran a weekly, full day maker class at the school. During the first part of the school year, prior to the winter break, we conducted structured orientation activities (workshops) centered on particular toolsets. Students could choose which workshops they wanted to join. For example, a student might choose to complete a sewing orientation one day, learning to thread the machine, sew a seam, and complete a small fabric bag, then choose an electronics orientation for the next session, learning how to complete a circuit with a battery, an LED, and a potentiometer. Workshops included sewing, electronics, woodworking, laser cutting, 
and 3D printing. Following this initial workshop time, the class structure became highly openended, with students having substantial autonomy to work on projects of their own choosing. Students were guided through the design process, with activities to scaffold ideation, prototyping, building, testing, and iterating, but the majority of the time was open workshop time. Students were encouraged to complete a project to share at the Maker Faire, a large regional exposition of maker projects held in the San Francisco Bay Area each spring.

At the end of each session, we conducted brief, 2 to 6 minute video-recorded interviews with students. Interview questions varied, but always asked students a) what they worked on that day and $b$ ) if they encountered any sticking points in their work. These interviews constitute the data for this paper. Data collection spanned two and a half school years.

Participants in the full study were 40 students who enrolled for at least some portion of the school year. This group was racially diverse: $2.5 \%$ were Asian, $25 \%$ were Black, $17.5 \%$ were Latino/a, 35\% were White, and $20 \%$ were two or more races; $47.5 \%$ were girls, $47.5 \%$ were boys, and 5\% were gender non-conforming. Across this full group, our data corpus consists of approximately 600 short interviews. For this paper, we analyze a subset of this data corpus, namely the data for 9 students who enrolled in the class for 2 or more years and completed 20 or more interviews each. This yielded 235 interviews for analysis, with an average of 26 interviews per student.

\section{Data analysis}

We transcribed the full set of interview data. Then, as a first pass, we coded for statements that had a self-efficacy component. We included both statements where students made explicit, metacognitive assessments of their own abilities (e.g., "I think that's a pretty easy project for me to do because it's a box. I've done it before. So I think that'll be pretty quick."), as well as statements where the assessment was implicit, but reported on work in a way that we believed was meant to generalize beyond that one instance ("You like something and then you search it up on the internet and then you can laser cut it and then just put it up in your room. That's pretty cool."). We were fairly conservative in this regard, coding just under one statement per interview, on average. This process yielded 211 statements coded as relevant to self-efficacy.

We extended this initial pass into a process of thematic coding [13]. First, we conducted open coding over those 211 examples. This process yielded 29 distinct codes. We then began the process of searching for themes, consolidating codes in the process. We organized the codes into three high-level themes: the ability to execute or carry out actions in the makerspace; the ability to learn in the makerspace; and one's affect (emotion) in relation to the makerspace. We divided each of these major themes into a number of subcodes, yielding 11 subcodes all together.

\section{Findings}

The results of our thematic coding process is summarized in Table 1. It shows the names of the codes, their relative frequencies, and an example statement for each subcode. 
Table 1. Thematic codes, their frequency, and examples

\begin{tabular}{|c|c|c|}
\hline Code & Pet & Example quote \\
\hline Execute & $49 \%$ & \\
\hline $\begin{array}{l}\text { Generate } \\
\text { Ideas }\end{array}$ & $4 \%$ & $\begin{array}{l}\text { Because I asked for a smaller piece of acrylic than I actually needed I } \\
\text { had to make changes here. I had to make slight changes in the design. I } \\
\text { figured out how to do all that. }\end{array}$ \\
\hline $\begin{array}{l}\text { Help / } \\
\text { Teach }\end{array}$ & $4 \%$ & $\begin{array}{l}\text { Mostly I helped my friend [Tim] with his project, the box drum. So I } \\
\text { helped him cut out a box, like a rectangle with a laser cutter, and I added } \\
\text { this cool design on there as well. }\end{array}$ \\
\hline $\begin{array}{l}\text { Overcome } \\
\text { sticking } \\
\text { point }\end{array}$ & $9 \%$ & $\begin{array}{l}\text { I'm ready for any challenge ... I have to keep trying even though if, like } \\
\text { say when the computer was shutting down on me, I just didn't give up. } \\
\text { Not give up when I have sticking points, but keep trying. }\end{array}$ \\
\hline $\begin{array}{l}\text { Multi-step } \\
\text { plan }\end{array}$ & $13 \%$ & $\begin{array}{l}\text { My confidence level is pretty high. We've got a project going on, } \\
\text { actually, we're in the process of just the very basics of creating a } \\
\text { vacuform table, so we've started a base. We're attaching the legs very } \\
\text { soon... }\end{array}$ \\
\hline $\begin{array}{l}\text { Project } \\
\text { task }\end{array}$ & $9 \%$ & $\begin{array}{l}\text { I think that's a pretty easy project for me to do because it's a box. I've } \\
\text { done it before. So I think that'll be pretty quick. }\end{array}$ \\
\hline Skill & $9 \%$ & $\begin{array}{l}\text { I guess the most challenging was working with Inkscape. It's sort of hard } \\
\text { software to get used to so that was mostly a challenge but I feel like I got } \\
\text { the basics down so far. I feel really good about that. }\end{array}$ \\
\hline Affect & $20 \%$ & \\
\hline $\begin{array}{l}\text { Identity / } \\
\text { Excitement }\end{array}$ & $10 \%$ & $\begin{array}{l}\text { I really, really, really like electronics and I kind of want to get more } \\
\text { people into it because not many people really know about it or know } \\
\text { anything about it }\end{array}$ \\
\hline Fear & $4 \%$ & $\begin{array}{l}\text { The soldering. Because I was really nervous to do that. I was super } \\
\text { nervous and my hands were shaking. I thought I was going to do it } \\
\text { wrong and have to buy a whole new strand of LEDs. }\end{array}$ \\
\hline Pride & $6 \%$ & $\begin{array}{l}\text { I'm most excited about how the hood looks a lot better... I feel really } \\
\text { proud though. It's my first cloak and it looks good. }\end{array}$ \\
\hline Learn & $30 \%$ & \\
\hline $\begin{array}{l}\text { Improve } \\
\text { existing } \\
\text { skill }\end{array}$ & $19 \%$ & $\begin{array}{l}\text { When we were playing with the LED lights, and we were playing with } \\
\text { the motors and everything. We were trying to connect all the cables, and } \\
\text { it was super complicated in my head, but then I figured out how to do it, } \\
\text { and I'm good at it now. }\end{array}$ \\
\hline $\begin{array}{l}\text { Learn } \\
\text { something } \\
\text { new }\end{array}$ & $11 \%$ & $\begin{array}{l}\text { I understood more about how laser cutting works because I really didn't } \\
\text { know anything about it until today, until you were helping us and } \\
\text { explaining the process of laser cutting. }\end{array}$ \\
\hline
\end{tabular}


We note that there is potential overlap across some of the subcodes. For the execute codes, for example, skill, project task, and multi-step plan codes are all similar, but are divided based on the activity being completed. If someone referred to their skill on a particular tool, like using the laser cutter, we coded this as a skill statement. If they instead talked about their ability to complete a task for their project, such as laser-cut a piece for a larger project, we coded this as project task. If their statement referred to their ability to complete multiple steps for part of a project, we coded this as multi-step plan. Clearly, these subcodes are related, but we felt it was useful to distinguish among differing sizes of the task or project, as we hypothesize that, over time, students will gain confidence in taking on longer and more complex tasks (we will test this hypothesis in planned analyses). Similarly, we distinguished between assessments of one's ability to improve an existing skill vs. the ability to learn in a novel, untested area.

\section{Discussion and conclusion}

Preliminary findings show that agency is a multi-faceted construct. We believe that the three toplevel codes - execute, learn, and affect - offer an interesting insight into the ways in which selfefficacy operated in this makerspace. We note in particular that $20 \%$ of codes referred to affective dimensions - what students were excited about, what they feared, and how making fit in with their developing sense of who they are. This was an unexpected finding that emerged from the data, and one we hope to investigate further. Likewise, it is notable that, because this is a learning space, students often commented on their ability to learn, both in improving their existing skills and in branching out to new areas.

Analysis is ongoing, and we plan to conduct further analyses on three fronts. First, we plan to complete a second coder pass and calculate interrater reliability. Second, we plan to analyze trends over time to see how particular themes emerge and change over time. For example, do students move from skill to project task to multi-step plan statements over time? Third, we plan to look for interrelations between codes over time. Do affective codes co-occur more often with learning codes or execute codes. Is pride more strongly associated with learning, with overcoming obstacles, or in completing tasks?

Because maker environments have been hypothesized to support the development of interest and engagement in engineering, and because self-efficacy is such an important predictor of student success and future engagement across domains, it is important to understand how self-efficacy develops, and how it is expressed, in maker learning environments. We believe this work-inprogress paper makes a substantive contribution in this regard. 


\section{References}

[1] P. Blikstein, "Digital fabrication and 'making'in education: The democratization of invention," FabLabs: Of Machines, Makers and Inventors, pp. 1-21, 2013.

[2] L. Martin and C. Dixon, "Making as a pathway to engineering and design," in Makeology: Makers as learners. vol. 2, K. A. Peppler, E. R. Halverson, and Y. B. Kafai, Eds., ed New York: Routledge, 2016, pp. 183-195.

[3] D. A. Fields and W. L. King, "“So, I think I'm a Programmer Now": Developing Connected Learning for Adults in a University Craft Technologies Course," in International Society of the Learning Sciences, Boulder, CO, 2014, pp. 927-936.

[4] A. Calabrese Barton, E. Tan, and M. Shin, "Mobilities of criticality: Space-making, identity and agency in a youth-centered makerspace," in International Conference of the Learning Sciences, Singapore, 2016.

[5] A. Godwin, G. Potvin, Z. Hazari, and R. Lock, "Identity, critical agency, and engineering: An affective model for predicting engineering as a career choice," Journal of Engineering Education, vol. 105, pp. 312-340, 2016.

[6] A. Bandura, "Self-efficacy mechanism in human agency," American psychologist, vol. 37, p. 122, 1982.

[7] F. Pajares, "Self-Efficacy Beliefs in Academic Settings," Review of Educational Research, vol. 66, pp. 543-578, 1996.

[8] A. Bandura, C. Barbaranelli, G. V. Caprara, and C. Pastorelli, "Self-Efficacy Beliefs as Shapers of Children's Aspirations and Career Trajectories," Child Development, vol. 72, pp. 187-206, 2001.

[9] M. K. Ponton, J. H. Edmister, L. S. Ukeiley, and J. M. Seiner, "Understanding the Role of SelfEfficacy in Engineering Education," Journal of Engineering Education, vol. 90, pp. 247-251, 2001.

[10] A. R. Carberry, H. S. Lee, and M. W. Ohland, "Measuring engineering design self-efficacy," Journal of Engineering Education, vol. 99, pp. 71-79, 2010.

[11] T. D. Fantz, T. J. Siller, and M. A. Demiranda, "Pre-Collegiate Factors Influencing the Self-Efficacy of Engineering Students," Journal of Engineering Education, vol. 100, pp. 604-623, 2011.

[12] H. M. Matusovich, R. A. Streveler, and R. L. Miller, "Why Do Students Choose Engineering? A Qualitative, Longitudinal Investigation of Students' Motivational Values," Journal of Engineering Education, vol. 99, pp. 289-303, 2010.

[13] V. Braun and V. Clarke, "Using thematic analysis in psychology," Qualitative Research in Psychology, vol. 3, pp. 77-101, 2006/01/01 2006. 